\title{
Heterocycles in the Service of Humankind
}

\author{
Alan R. Katritzky* and Ekaterina Todadze \\ Center for Heterocyclic Compounds, Department of Chemistry, \\ University of Florida, Gainesville, FL 32611-7200 \\ E-mail: katritzky@,chem.ufl.edu
}

\section{Summary of Opening Lecture of the $6^{\text {th }}$ Eurasian Conference on Heterocyclic Chemistry, held March 2008 at Kuwait University}

\begin{abstract}
Alleviating the scourge of biting insects; Bioconjugates for new directions in pharmaceutical research; Sharing the benefits of research
\end{abstract}

Keywords: Malaria, insect repellents, bioconjugates, chemistry publishing

\section{Contents}

1. Overcoming the Problems of Biting Insects

2. Bioconjugates for New Directions in Pharma Research:Applications of Acylbenzotriazoles

3. Attempts to help Chemistry in Developing Countries by Innovations in the Publishing and Dissemination of Organic Chemistry Research

4. Attempts to help Chemistry in Developing Countries by Innovations in the Publishing and Dissemination of Organic Chemistry Research

1. Overcoming the Problems of Biting Insects (Research with the participation of U. Bernier, D. Dobchev, G. Clark, C. D. Hall, K. Linthicum, S. Slavov, M. Tsikolia, Z. Wang)

Mosquito-borne diseases such as malaria, arboviral encephalitis, dengue fever, Rift Valley fever, and yellow fever, still result in significant morbidity and mortality in humans. Insect repellents often serve as a first line of personal protection. Disadvantages of current repellents include limited duration of protection from insect bites due to evaporative loss, absorption into the skin, removal by dissolution in water, skin irritation and a stinging sensation when in contact with eyelids or lips. Some repellents are only efficient when used in large quantities on the skin or 
clothing. The repellent most often used is DEET but a major drawback is that DEET can lead to adverse side effects in some individuals, especially from its systemic uptake via dermal absorption.

New, improved long lasting repellents that are safe and efficacious against a wide range of insects are needed. Thus, there is a long-standing interest in the design of compounds that will be effective repellents against mosquitoes, sand flies, stable flies, black flies, tsetse flies, biting gnats and tabanids, all of which spread human and animal diseases.

Although the design of new insect repellents by computer-aided molecular modeling was discussed in a recent book, there have been few previous attempts to correlate the repellency of compounds towards mosquitoes with their chemical structure. ${ }^{2}$ Suryanarayana et al. ${ }^{1}$ used a small set of 31 repellants to propose the model (eqn 1) with the rather low $\mathrm{R}^{2}$ of 0.304 : where PT $=$ Protection Time; $\log P=$ lipophilicity; $V \mathrm{p}=$ Vapor pressure; $M L=$ Molecular Length.

$$
\mathrm{PT}=\mathbf{a} \log P+\mathbf{b} \log V \mathrm{p}+\mathbf{c} \log M L+d
$$

With the same data-set, and using descriptors derived solely from the chemical structures of the repellants we found an improved model with an $\mathrm{R}^{2}$ of 0.79 . This encouraged us to go further. Over the last few years we have been collaborating with the U.S. Department of Agriculture at the University of Florida, which over the past 60 years have recorded tests covering a wide range of insect species and some 30,000 different compounds. Properties such as protection time, effective dose and lethal dose towards a large numbers of insects including various species of mosquitoes, houseflies and other pests were amassed. We were given access to these records and in agreement with the Department of Agriculture embarked on a program to try and extract from them some information that would allow us to understand the relationship between the biological activity of compounds and their chemical structures. This lecture concerns the work that we have carried out with $N$-acylpiperidines, and which is described in detail in Proc. Nat. Acad. Sci. USA, 2008.

The USDA records included more than 150 different $N$-acylpiperidines which had been tested for their effectiveness as mosquito repellants. These compounds were classified according to their effectiveness into five classes, 1 being the least active and class 5 being the most active. The most active compounds retained effectiveness for 21 days. By building a neural network model, we were able to correlate protection times from the old USDA data with the chemical structures as is shown in Figure 1. 


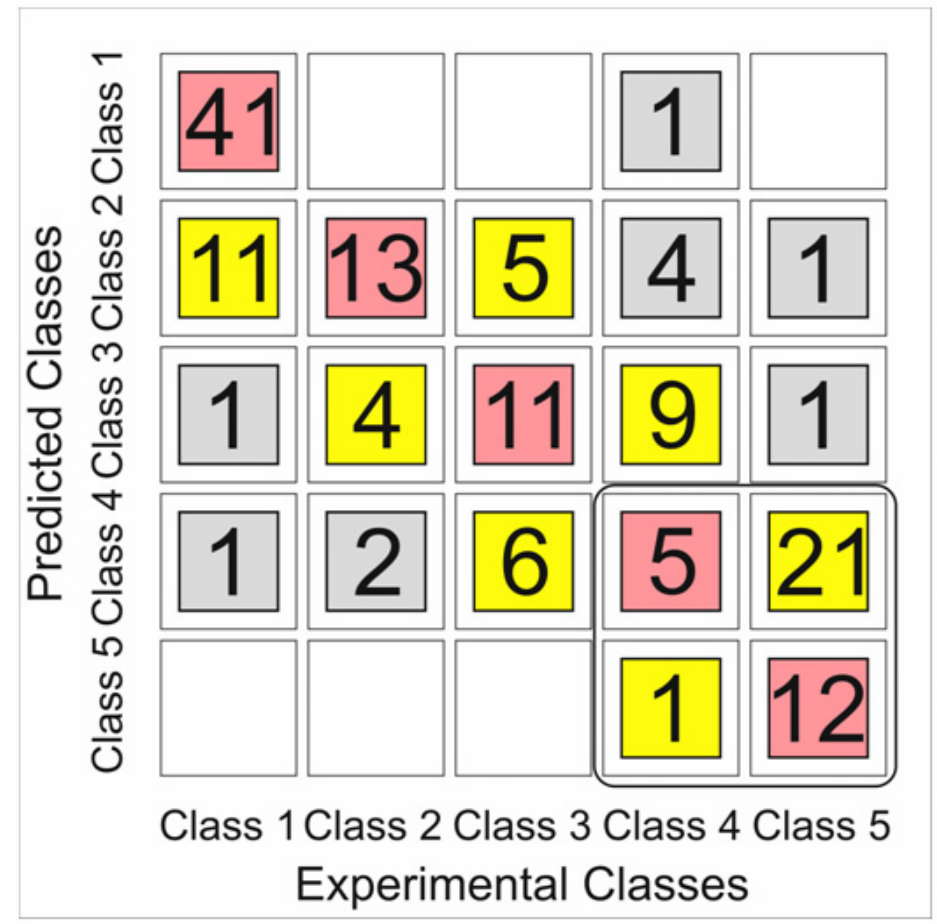

\begin{tabular}{c|c} 
Class & Prediction \\
\hline-3 & 2 \\
\hline-2 & 5 \\
\hline-1 & 35 \\
\hline on spot & 82 \\
\hline+1 & 22 \\
\hline+2 & 3 \\
\hline+3 & 1
\end{tabular}

Figure 1. Correlation of protection times (old USDA data) with chemical structures by ANN.

We re-synthesized 11 of the $N$-acylpiperidines that were previously tested in order to anchor the envisaged biological testing into the existing data. Piperidines were synthesized utilizing acylbenzotriazoles prepared from carboxylic acids by treatment with thionyl chloride and benzotriazole. In addition to the 11 previously tested $N$-acylpiperidines, we synthesized 23 novel $N$-acylpiperidines as potential repellants. These 23 compounds were selected by first using our neural network model to predict the likely activity of many hundreds of compounds. Most of the 23 compounds selected were expected to be highly active but a few were also chosen that were predicted to have lower activity.

Biological testing was carried out for all $23+11=34$ compounds synthesized, together with DEET. Bioassays were conducted by covering the hand of a volunteer with a soft-embossed long cuff poly glove and powder-free latex glove. To cover the arm a stocking is pulled over. A sleeve with an opening $(3 \mathrm{~cm} \times 8 \mathrm{~cm}$ ) was fastened around the arm. Each cloth patch assembly was affixed over the open window with masking tape to hold it in place on the sleeve. The arm is then inserted into the cage of mosquitoes and held stationary for 1 minute. The number of feeding mosquitoes was counted prior to removal with a quick, brisk shake of the arm. Feeding mosquitoes that remained in the window were considered to have been biting. 
The failure threshold for repellency for these experiments was set at $1 \%$ biting ( 5 bites) confirmed by achievement of two consecutive days of 5 or more bites. The results are shown in Table 1 and graphically in Figure 2. Gratifyingly, several of the compounds prepared showed considerably improved protection times compared to DEET.

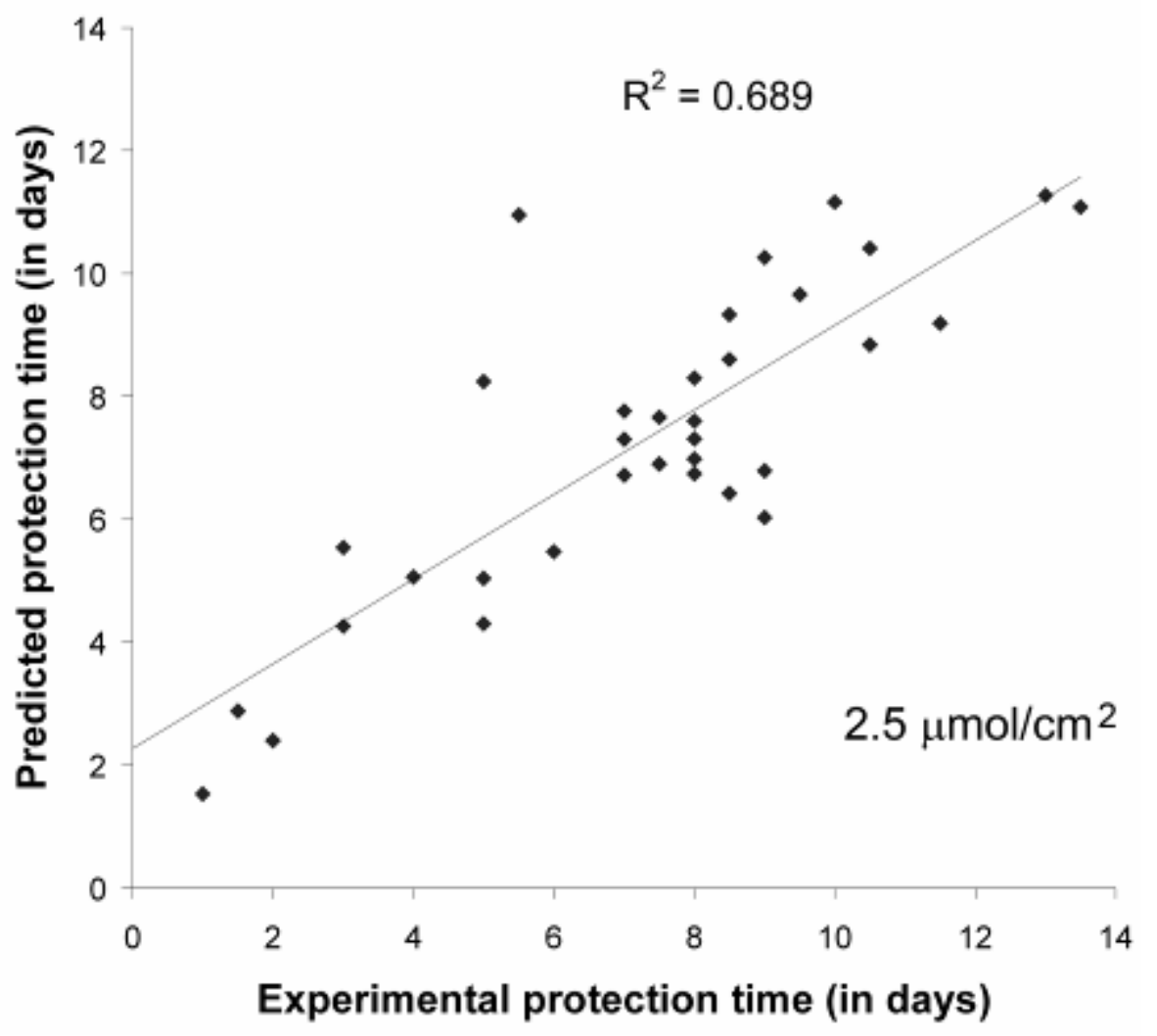

Figure 2. Correlation of protection time with chemical structure for the newly synthesized Nacylpiperidines.

The structures of the most effective compounds and their protection times are compared with DEET in Figure 3. These compounds are now being subjected to toxicity and other tests to see if they can be applied. We have particularly not asked for any patent protection for any of this work in order to make the results available to the whole world as quickly as possible. 
Table 1. Average protection time in days

\begin{tabular}{|c|c|c|c|c|c|c|c|c|c|}
\hline \multicolumn{3}{|c|}{ Compound } & \multicolumn{2}{|c|}{ Average PT } & \multicolumn{3}{|c|}{ Compound } & \multicolumn{2}{|c|}{ Average PT } \\
\hline ID \# & $\mathrm{R}$ & $\mathrm{R}^{\prime}$ & $\begin{array}{c}25 \\
\mu \mathrm{mol}^{\prime} / \mathrm{cm}^{2}\end{array}$ & $\begin{array}{c}2.5 \\
\mu \mathrm{mol} / \mathrm{cm}^{2}\end{array}$ & ID \# & $\mathrm{R}$ & $\mathrm{R}^{\prime}$ & $\begin{array}{c}25 \\
\mu \mathrm{mol} / \mathrm{cm}^{2}\end{array}$ & $\begin{array}{c}2.5 \\
\mu \mathrm{mol}^{\prime} \mathrm{cm}^{2}\end{array}$ \\
\hline DEET & & & 17.5 & 2.5 & & & & & \\
\hline $4 a$ & $\mathrm{Me}$ & $2-\mathrm{Me}$ & 2 & 2 & $4 a^{\prime *}$ & $1-c-\mathrm{C}_{6} \mathrm{H}_{9}$ & $\mathrm{H}$ & 17 & 5 \\
\hline $4 \mathrm{~b}$ & Et & $\mathrm{H}$ & 5 & 4 & $4 \mathrm{~b}^{\prime *}$ & $c-\mathrm{C}_{6} \mathrm{H}_{11}$ & $\mathrm{H}$ & 14 & 8 \\
\hline $4 c$ & Et & 2-Et & 5 & 3 & $4 c^{\prime *}$ & $c-\mathrm{C}_{6} \mathrm{H}_{11}$ & 3-Me & 17 & 6 \\
\hline $4 d$ & $n-\mathrm{C}_{6} \mathrm{H}_{13}$ & $2-\mathrm{Me}$ & 17 & 5 & $4 d^{\prime *}$ & $c-\mathrm{C}_{6} \mathrm{H}_{11}$ & $4 \mathrm{Me}$ & 24.5 & 8.5 \\
\hline $4 e$ & $n-\mathrm{C}_{6} \mathrm{H}_{13}$ & 3-Me & 15.5 & 7.5 & $4 e^{\prime *}$ & $c-\mathrm{C}_{5} \mathrm{H}_{9}\left(\mathrm{CH}_{2}\right)_{2}$ & $\mathrm{H}$ & 35 & 9 \\
\hline $4 \mathbf{f}$ & $n-C_{7} \mathrm{H}_{15}$ & $4 \mathrm{Me}$ & 48 & 8 & $4 f^{*}$ & $1-\mathrm{Me}-\mathrm{c}-\mathrm{C}_{6} \mathrm{H}_{10}$ & 3-Me & 12 & 7 \\
\hline $4 g$ & $n-\mathrm{C}_{7} \mathrm{H}_{15}$ & $4 \mathrm{Bn}$ & 13 & 7 & $4 g^{\prime}$ & $4 \mathrm{Me}-c-\mathrm{C}_{6} \mathrm{H}_{10}$ & 2-Me & 33 & 8.5 \\
\hline 4h & $n-\mathrm{C}_{8} \mathrm{H}_{17}$ & 2-Et & 43 & 9.5 & $4 h^{* *}$ & $c-\mathrm{C}_{6} \mathrm{H}_{11}$ & $2-\mathrm{Et}$ & 21.5 & 7 \\
\hline $4 \mathbf{i}$ & $n-\mathrm{C}_{9} \mathrm{H}_{19}$ & $2-\mathrm{Me}$ & 49.5 & 8 & $4 i^{\prime *}$ & $c-\mathrm{C}_{6} \mathrm{H}_{11} \mathrm{CH}_{2}$ & 2-Me & 29.5 & 7.5 \\
\hline $4 j$ & $n-\mathrm{C}_{9} \mathrm{H}_{19}$ & $4 \mathrm{Me}$ & 41 & 11.5 & $4 j^{\prime *}$ & $c-\mathrm{C}_{6} \mathrm{H}_{11}\left(\mathrm{CH}_{2}\right)_{2}$ & 2-Me & 47.5 & 10 \\
\hline $4 \mathbf{k}^{*}$ & $\mathrm{CH}_{2}=\mathrm{CH}\left(\mathrm{CH}_{2}\right)$ & $\mathrm{H}$ & 50 & 13.5 & $4 k^{* *}$ & $c-\mathrm{C}_{6} \mathrm{H}_{11}\left(\mathrm{CH}_{2}\right)_{2}$ & 3-Me & 35 & 9 \\
\hline 41 & $\mathrm{CH}_{2}=\mathrm{CH}\left(\mathrm{CH}_{2}\right)$ & 2-Et & 53 & 9 & $41^{\prime}$ & $c-\mathrm{C}_{6} \mathrm{H}_{11}\left(\mathrm{CH}_{2}\right)_{2}$ & $4 \mathrm{Me}$ & 45.5 & 8 \\
\hline $4 m$ & $\mathrm{CH}_{2}=\mathrm{CH}\left(\mathrm{CH}_{2}\right)$ & $4 \mathrm{Bn}$ & 8.5 & 8 & $4 m^{\prime}$ & $c-\mathrm{C}_{6} \mathrm{H}_{11}\left(\mathrm{CH}_{2}\right)_{3}$ & $4 \mathrm{Me}$ & 33 & 3 \\
\hline $4 n$ & $\mathrm{CH}_{2}=\mathrm{CH}\left(\mathrm{CH}_{2}\right)$ & $4 \mathrm{Me}$ & 73 & 10.5 & $4 n^{\prime}$ & $c-\mathrm{C}_{5} \mathrm{H}_{9}\left(\mathrm{CH}_{2}\right)_{2}$ & 2 -Et & 40.5 & 8.5 \\
\hline 40 & $n-\mathrm{C}_{10} \mathrm{H}_{21}$ & $\mathrm{H}$ & 39.5 & 13 & $40^{\circ}$ & $c-\mathrm{C}_{6} \mathrm{H}_{11}\left(\mathrm{CH}_{2}\right)_{2}$ & $2-\mathrm{Et}$ & 42 & 10.5 \\
\hline $4 p$ & $n-\mathrm{C}_{11} \mathrm{H}_{23}$ & $2-\mathrm{Me}$ & 14.5 & 5 & $4 p^{\prime}$ & $c-\mathrm{C}_{6} \mathrm{H}_{11} \mathrm{CH}_{2}$ & $4 \mathrm{Bn}$ & 3 & 1.5 \\
\hline $4 q$ & $n-\mathrm{C}_{11} \mathrm{H}_{23}$ & 3-Me & 19.5 & 5.5 & $4 q^{\prime}$ & $c-\mathrm{C}_{6} \mathrm{H}_{11}\left(\mathrm{CH}_{2}\right)_{2}$ & $4 \mathrm{Bn}$ & 12 & 1 \\
\hline
\end{tabular}

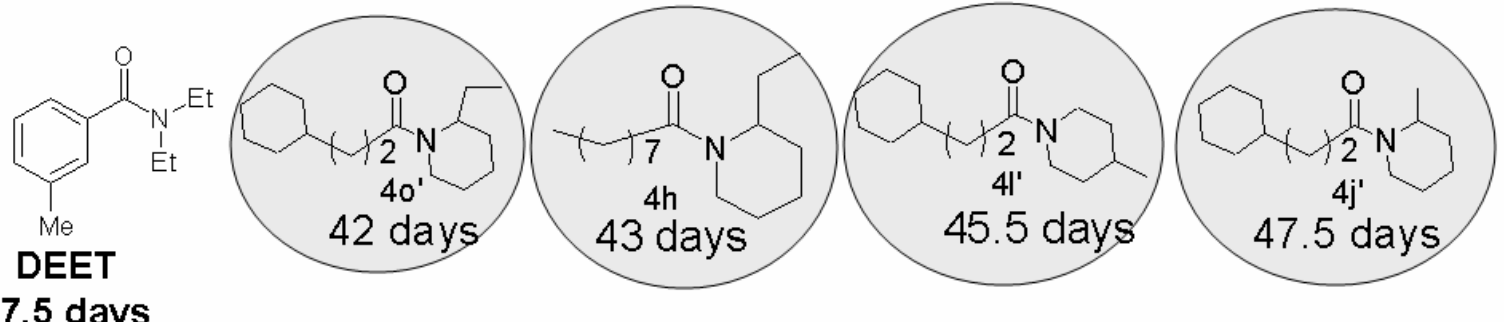

17.5 days

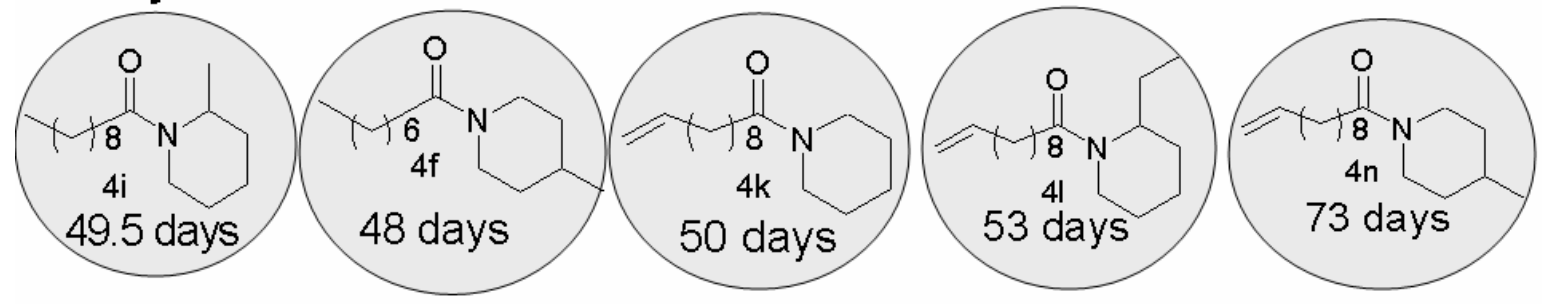

Figure 3. Protection time $\left(25 \mu \mathrm{mol} / \mathrm{cm}^{2}\right)$ and structures. 


\section{Bioconjugates for New Directions in Pharma Research: Applications of} Acylbenzotriazoles. (Research with the participation of P. Angrish, B. E.-D. M. El-Gendy, D. Haase, L. Khelashvili, T. Narindoshvili, S. Tala)

The pharmaceutical industry is in crisis. It is becoming increasingly difficult to find new major drugs. Many of the time-honored strategies for drug research seem to be failing. One direction that is opening up is that of bioconjugates. Bioconjugates can be defined as compounds in which at least two fundamentally different types of organic structure are linked together. Table 2 shows the possibilities considering two out of six compound classes to be linked to each other or to another class. Some of the different types of bioconjugates displayed in Table 2 are very well known, but others have hardly been studied.

Table 2. Bioconjugates for new directions in pharma research

\begin{tabular}{|c|c|c|c|c|c|c|}
\hline & Amino Acids & $\begin{array}{c}\text { Mono } \\
\text { Saccharides }\end{array}$ & Lipids & $\begin{array}{l}\text { Steroids } \\
\text { Terpenes }\end{array}$ & Porphyrins & Biomarkers \\
\hline Amino Acids & Proteins & $\begin{array}{l}\text { Glycoproteins } \\
\text { Glycopeptides }\end{array}$ & $\begin{array}{c}\text { Lipoprotein } \\
\text { Lipoamino } \\
\text { acids } \\
\text { Lipopeptides }\end{array}$ & $\begin{array}{l}\text { Peptidyl } \\
\text { steroids }\end{array}$ & $\begin{array}{l}\text { Porphyrin-amino } \\
\text { acid derivatives }\end{array}$ & $\begin{array}{l}\text { Biomarked } \\
\text { amino acids }\end{array}$ \\
\hline $\begin{array}{l}\text { Mono } \\
\text { Saccharides }\end{array}$ & $\begin{array}{l}\text { Glycoproteins } \\
\text { Glycopeptides }\end{array}$ & $\begin{array}{l}\text { Sugars } \\
\text { Starches }\end{array}$ & $\begin{array}{l}\text { Glycolipids } \\
\text { Lipopolysacch } \\
\text { aride }\end{array}$ & $\begin{array}{l}\text { Steroidal } \\
\text { glycosides }\end{array}$ & Glycoporphyrins & $\begin{array}{c}\text { Biomarked } \\
\text { carbohydrates }\end{array}$ \\
\hline Lipids & $\begin{array}{l}\text { Lipoprotein } \\
\text { Lipoamino } \\
\text { acids } \\
\text { Lipopeptides }\end{array}$ & $\begin{array}{c}\text { Glycolipids } \\
\text { Lipopolysaccharide }\end{array}$ & Fats & Lipoproteins & Lipoporphyrins & $\begin{array}{l}\text { Biomarked } \\
\text { lipids }\end{array}$ \\
\hline $\begin{array}{l}\text { Steroids } \\
\text { Terpenes }\end{array}$ & $\begin{array}{l}\text { Peptidyl } \\
\text { steroids }\end{array}$ & Steroidal glycosides & Lipoproteins & $\begin{array}{l}\text { Higher } \\
\text { Terpenoids }\end{array}$ & $\longrightarrow$ & $\begin{array}{l}\text { Biomarked } \\
\text { steroids }\end{array}$ \\
\hline Porphyrins & $\begin{array}{l}\text { Porphyrin- } \\
\text { amino acid } \\
\text { derivatives }\end{array}$ & Glycoporphyrins & Lipoporphryins & - & Polyporphyrins & $\begin{array}{l}\text { Biomarked } \\
\text { porphyrins }\end{array}$ \\
\hline Biomarkers & $\begin{array}{l}\text { Amino acid } \\
\text { biomarkers }\end{array}$ & $\begin{array}{l}\text { Carbohydrate } \\
\text { biomarkers }\end{array}$ & $\begin{array}{l}\text { Lipid } \\
\text { biomarkers }\end{array}$ & $\begin{array}{c}\text { Steroid } \\
\text { biomarkers }\end{array}$ & $\begin{array}{l}\text { Porphyrin } \\
\text { biomarkers }\end{array}$ & \\
\hline
\end{tabular}

An easy and often convenient way of linking two structural units together in organic chemistry is acylation. The classical way to affect acylation uses acid chlorides, but there are disadvantages. Recently ${ }^{3}$ we introduced $N$-acylbenzotriazoles as substitutes for acid chlorides. Several advantages are associated with these reagents:

1. Preparation: rapid one-pot procedures with mild reaction conditions (THF; $20{ }^{\circ} \mathrm{C} ; 2 \mathrm{hr}$ )

$$
\mathrm{BtH}+\mathrm{SOCl}_{2} \rightarrow[\mathrm{BtSOBt}]+\mathrm{RCO}_{2} \mathrm{H} \rightarrow \mathrm{RCOBt} ; \mathrm{RCO}_{2} \mathrm{Na}+\mathrm{BtTs} \rightarrow \mathrm{RCOBt}+\mathrm{TsONa} .
$$

2. Isolation: easily in crystalline form; high yields and purity without chromatography.

3. Stability: can be weighed out and handled in air, and stored at $20^{\circ} \mathrm{C}$ for many weeks. 
4. Insensitive to water and thus can be used in partly aqueous solution: this allows peptidecoupling using amino acids with free carboxyl groups.

5. Protection not usually required for aliphatic or aromatic $-\mathrm{OH}$, heterocyclic $-\mathrm{NH}$, $-\mathrm{SH}$, or $\mathrm{CONH}_{2}$.

6. They are more reactive and more crystalline than acyl imidazoles.

7. The $\mathrm{Bt}$ group is readily replaced by $\mathrm{N}-, \mathrm{S}-, \mathrm{O}-$, and $\mathrm{C}-$ nucleophiles.

Acylbenzotriazoles can be applied to classical problems such as the synthesis of "difficult" peptide sequences, one of which is shown in Figure $4 .{ }^{4}$



Figure 4. Microwave-assisted solid phase synthesis of a short difficult pentapeptide. ${ }^{4}$ 


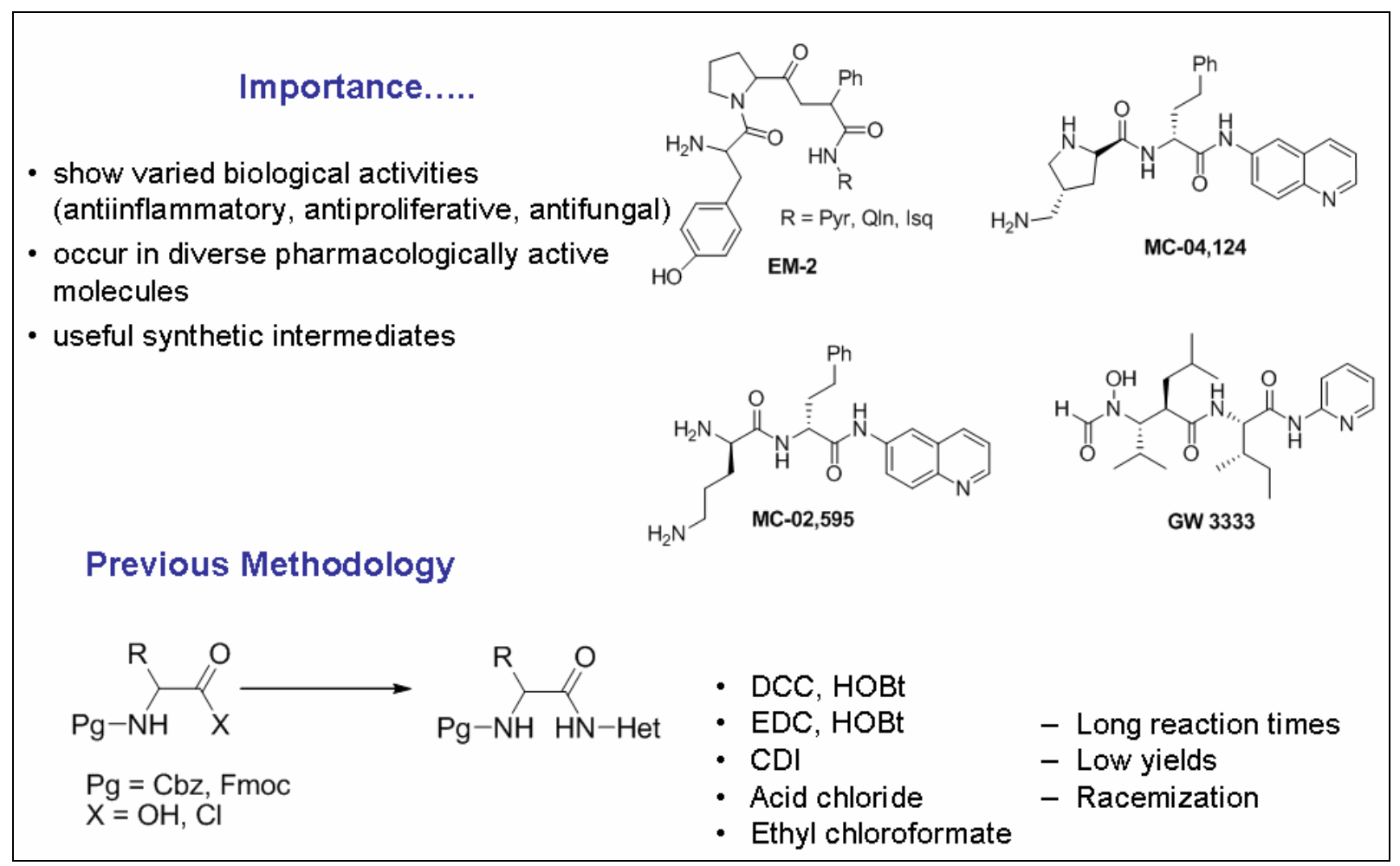

Figure 5. Importance and background for $\alpha$-aminoacylamino-substituted heterocycles.

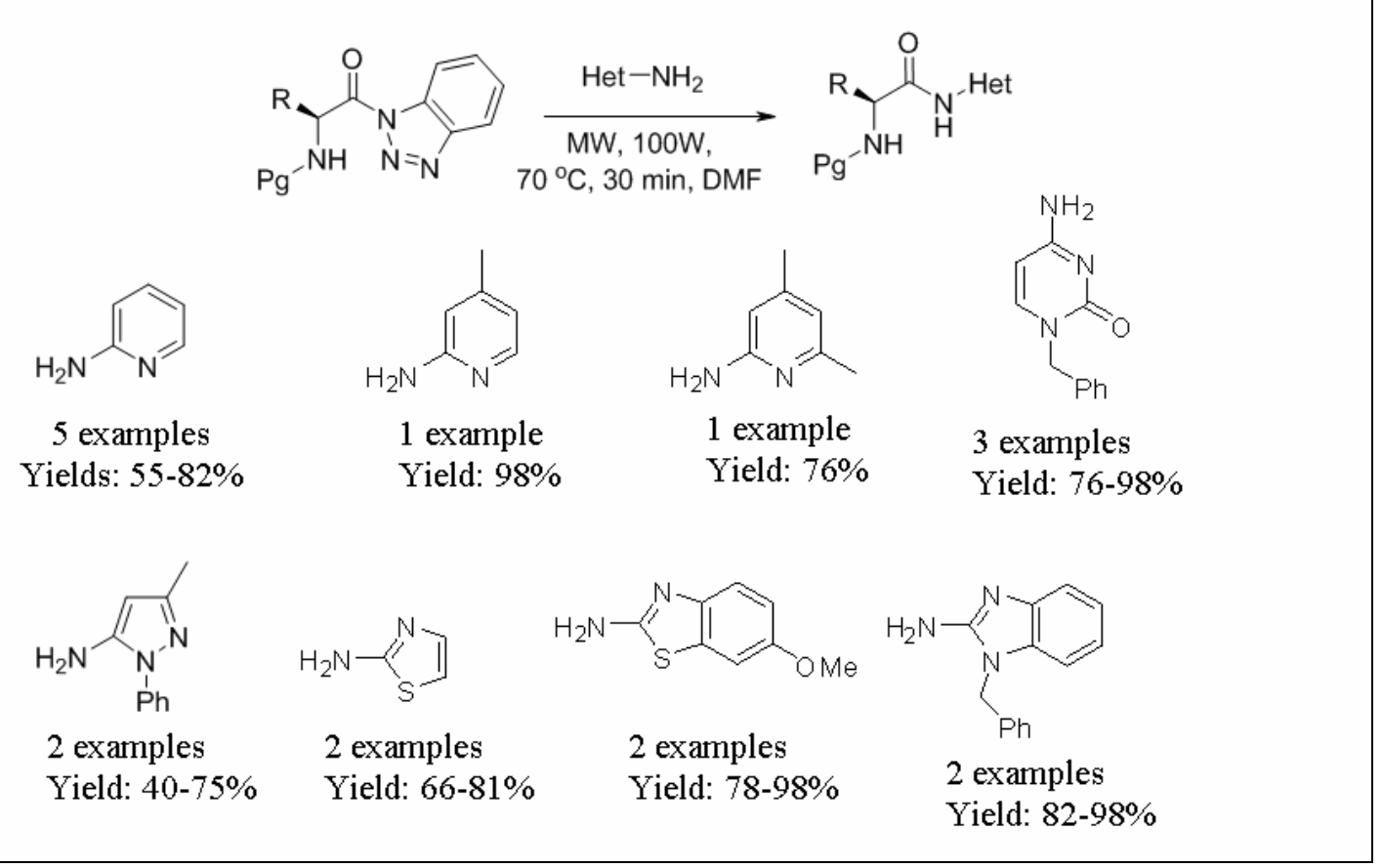

Figure 6. Novel $\alpha$-aminoacylamino-substituted heterocycles prepared. ${ }^{5}$ 
Another application ${ }^{5}$ is in the preparation of $\alpha$-aminoacylamino- substituted heterocycles which show many diverse biological activities. Figure 5 shows some examples of this, comparing the new methodology with the old, and resulting in the preparation of a diverse range of such compounds - additional examples of which are shown in Figure 6.

We have linked amino acids with terpenes through hydroxyl groups, as summarized in Figure 7. ${ }^{6}$ The data in Figure 7 also demonstrate the fact that chirality is preserved in the preparation and reactions of acylbenzotriazoles. Thus $D L$-Phe- $O$-citronellol shows retention times corresponding to each of the two diastereoisomers, whereas the analogous $L$-phenylalanine product shows only one peak.

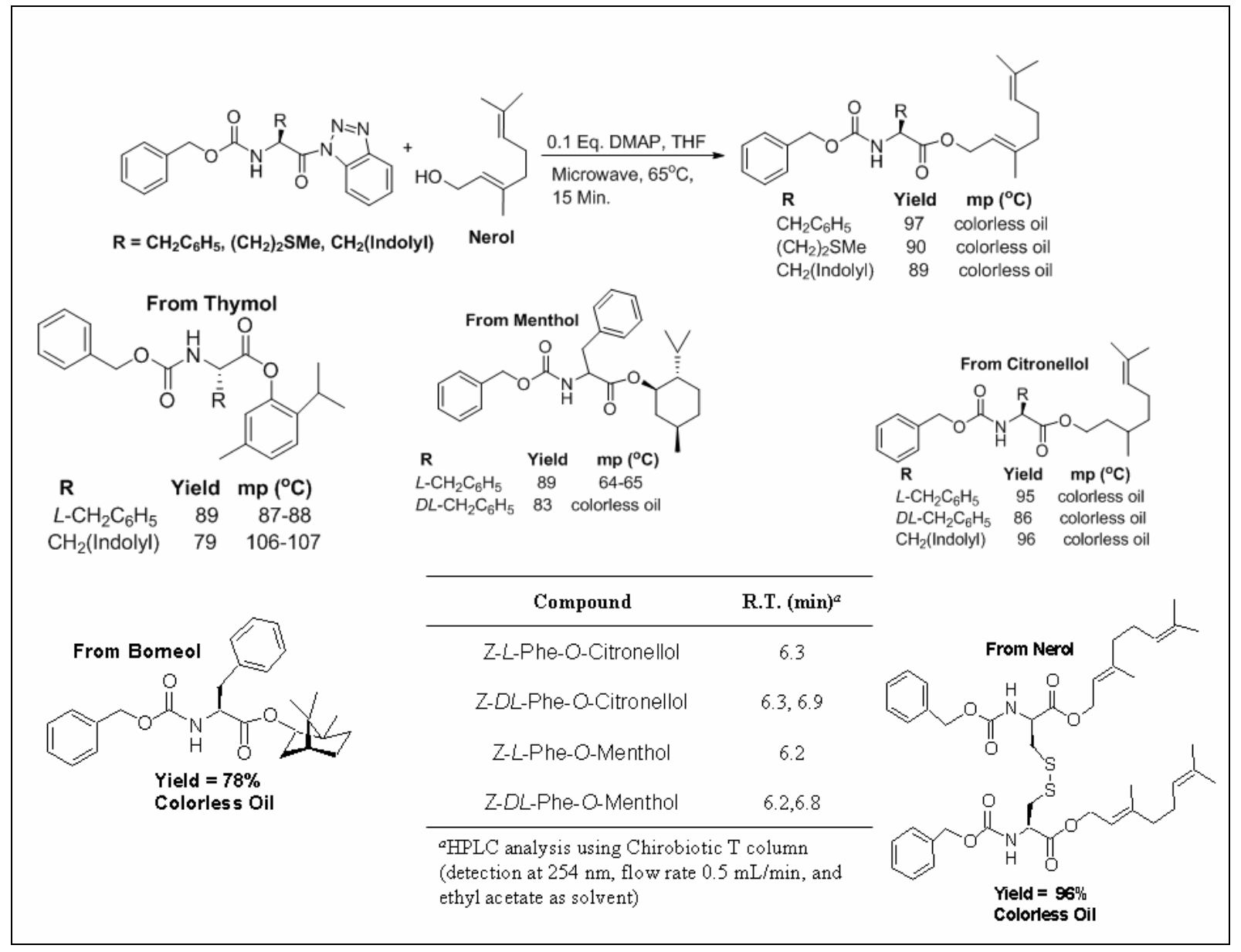

Figure 7. Preparation of $N$-protected ( $\alpha$-aminoacyl)oxy-substituted terpenes. ${ }^{6}$

Similarly amino- acid residues can be linked to steroids: Figure 8 shows some bioconjugates derived from cholesterol linked to a variety of amino acids. ${ }^{7}$ 


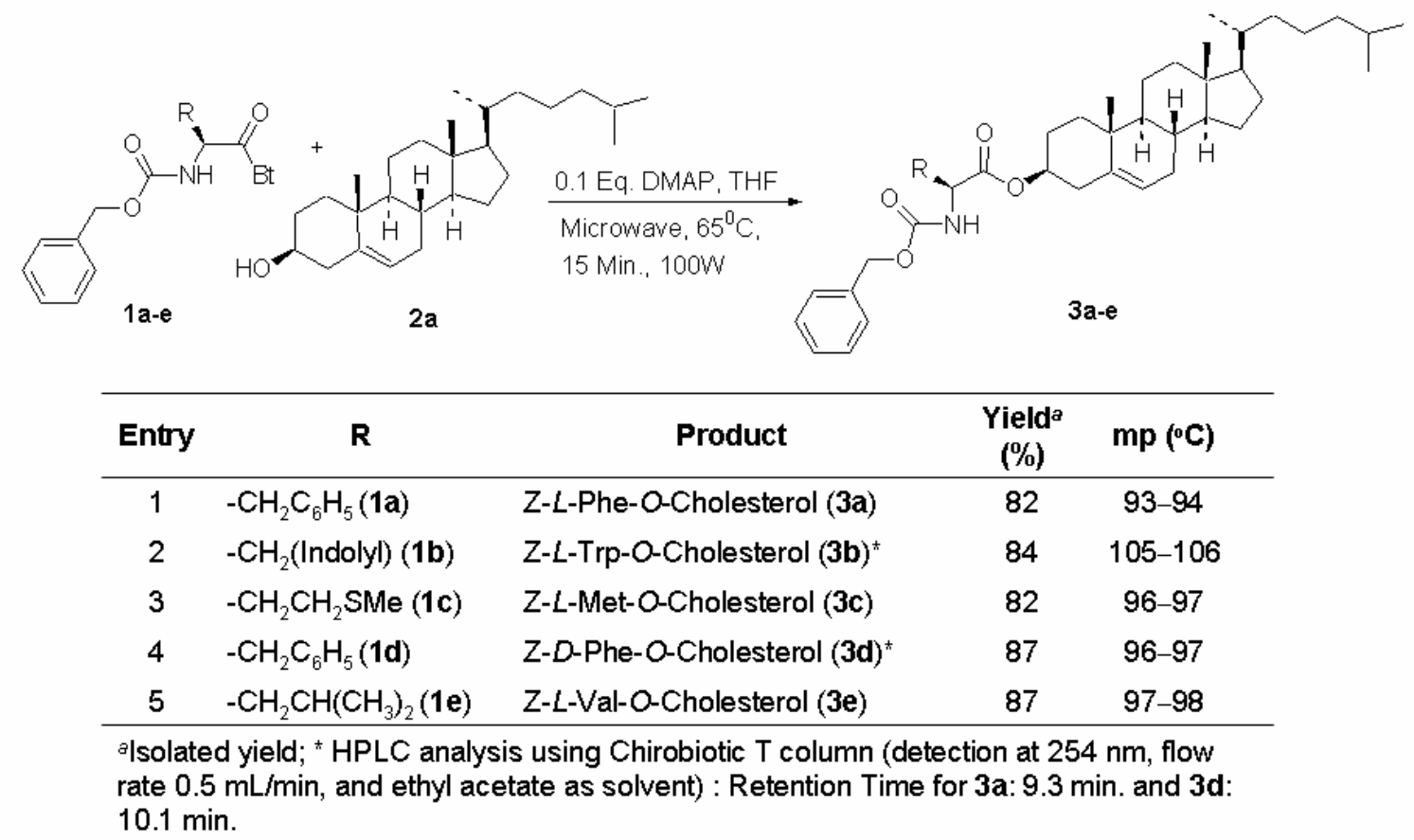

Figure 8. Microwave- assisted synthesis of $\alpha$-(protected-aminoacyl)oxysteroids. ${ }^{7}$

\begin{tabular}{|l} 
Stable Isotopic Labeling : labeling by including unusual, stable isotopes in chemical composition \\
Detection : Mass spectrometry and infrared spectroscopy. \\
Drawback: Expensive labeling and detection. \\
Iabelopic \\
Radioisotopic Labeling: Labeled by including radioisotopes in chemical composition. \\
Radioisotope undergoes radioactive decay, and emits gamma rays and/or subatomic particles. \\
Detection: By measuring the emitted radiation. \\
Drawback: Accident or poor disposal can cause a radioactive contamination of the \\
environment. \\
Covalently attaching a fluorophore to a biomolecule. \\
Detection: Labeled molecule is detected via fluorescence microscope or other fluorescence \\
reading instrument. \\
Common fluorescent dyes: Fluorescein, rhodamine, coumarin, Alexa Fluors, Dylight fluors. \\
Advantage: Cheap, easy, and very sensitive. \\
labeling \\
Introduction of chromophores into the biomolecule. \\
Being strongly absorbing in the visible region can be used for visual detection or colorimetric \\
probes. \\
To participate in Fluorescence Resonance Energy Transfer (FRET) as a quencher to develop \\
molecular beacons. \\
Advantage: Cheap labeling and detection under ambient conditions. \\
Dye labeling
\end{tabular}

Figure 9. Tagging techniques for molecules. 
Tagging has become extremely important for biomolecules (Figure 9).

Azo-dye- labeled $O$-aminoacyl terpenes, -sugars, and -steroids ${ }^{8}$ have been prepared by the new technique, as illustrated in Figure 10.

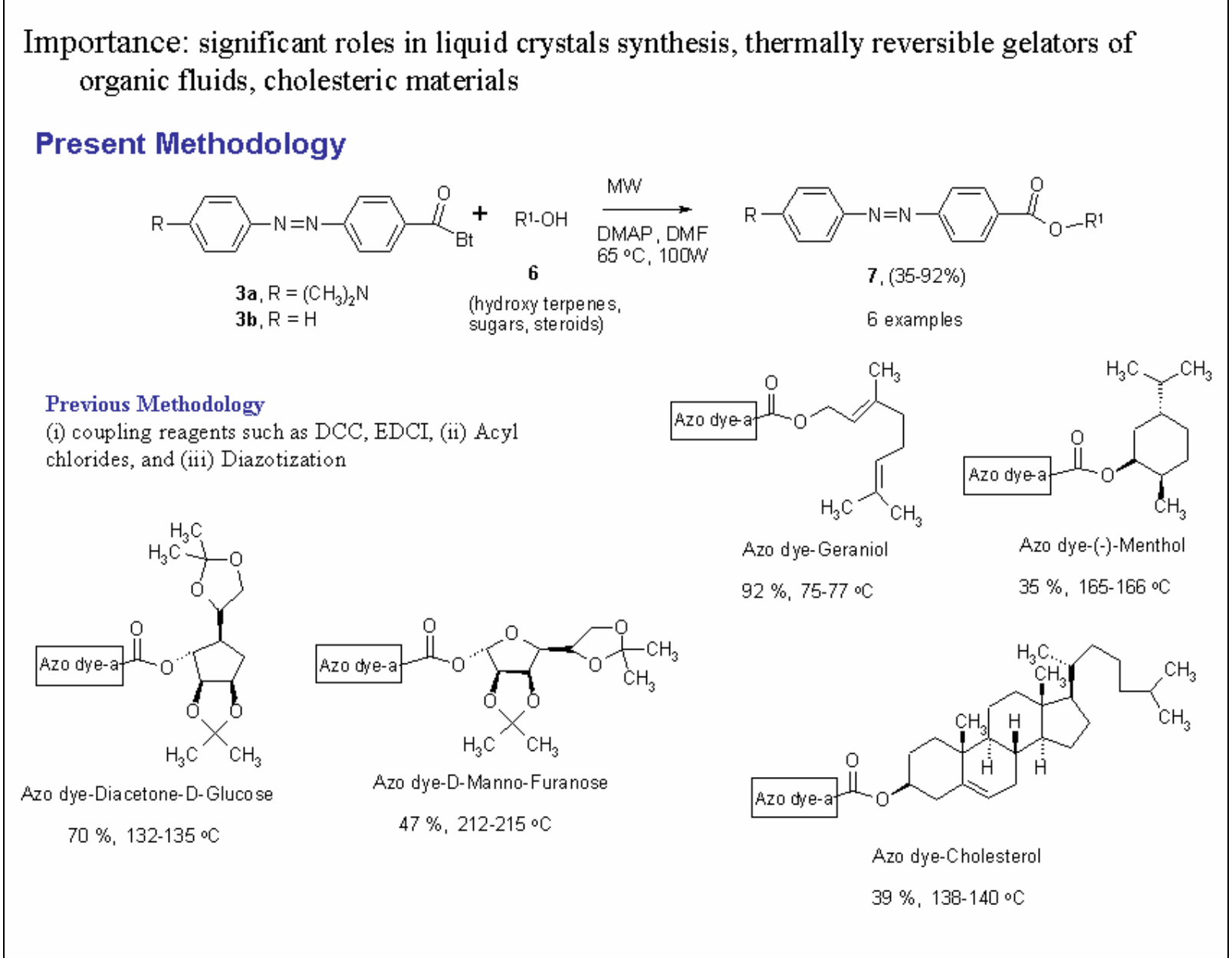

Figure 10. Preparation of azodye labeled terpenes, sugars and steroids. ${ }^{8}$

Fluorescent markers are often even more effective than dye markers. We have shown that coumarin units can be utilized in combination with lysine chemistry to tag a variety of amino acids and peptides ${ }^{9}$ (Figure 11).

Incorporation of a sugar unit confers solubility on such compounds and some examples of this technique ${ }^{10}$ are shown in Figure 12.

A series of dye- labeled nucleosides ${ }^{11}$ is shown in Figure 13.

Similar techniques have been applied to dye- label amino acids and dipeptide amino alcohols, ${ }^{12}$ as shown in Figure 14. 


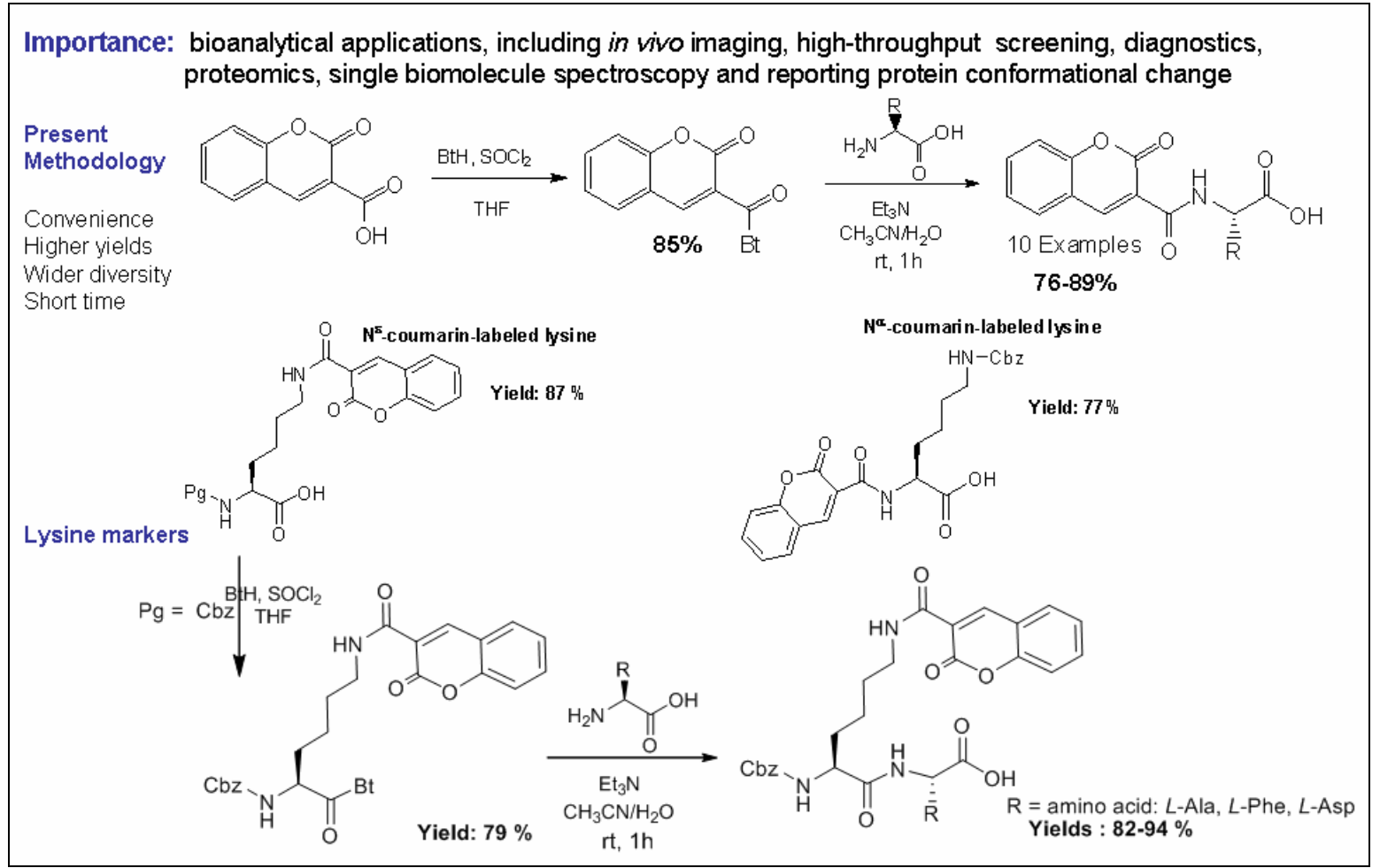

Figure 11. Fluorescent markers for amino acids and dipeptides. ${ }^{9}$

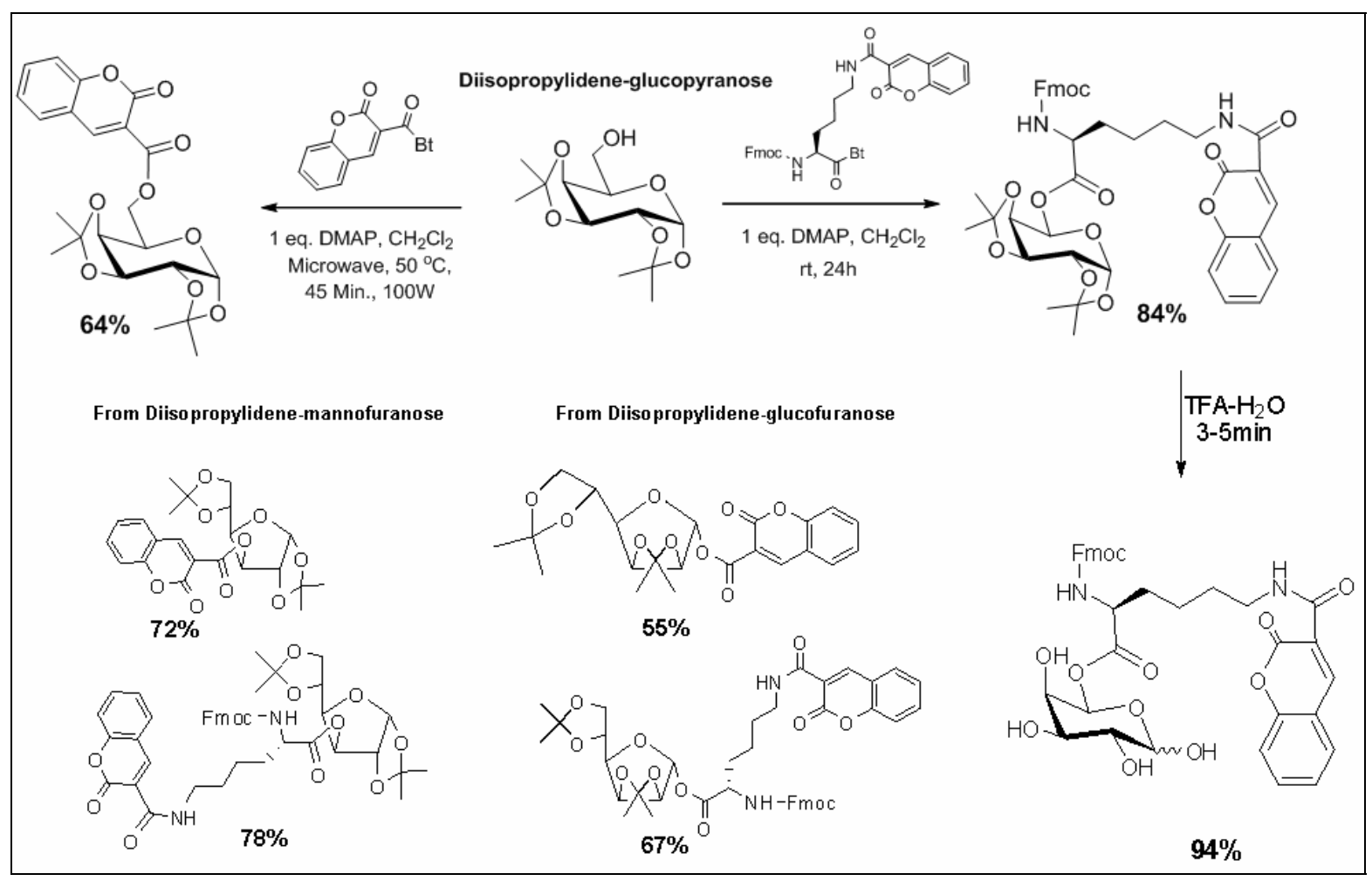

Figure 12. $O$-Labeled sugars and water-soluble fluorescent tags. ${ }^{10}$ 


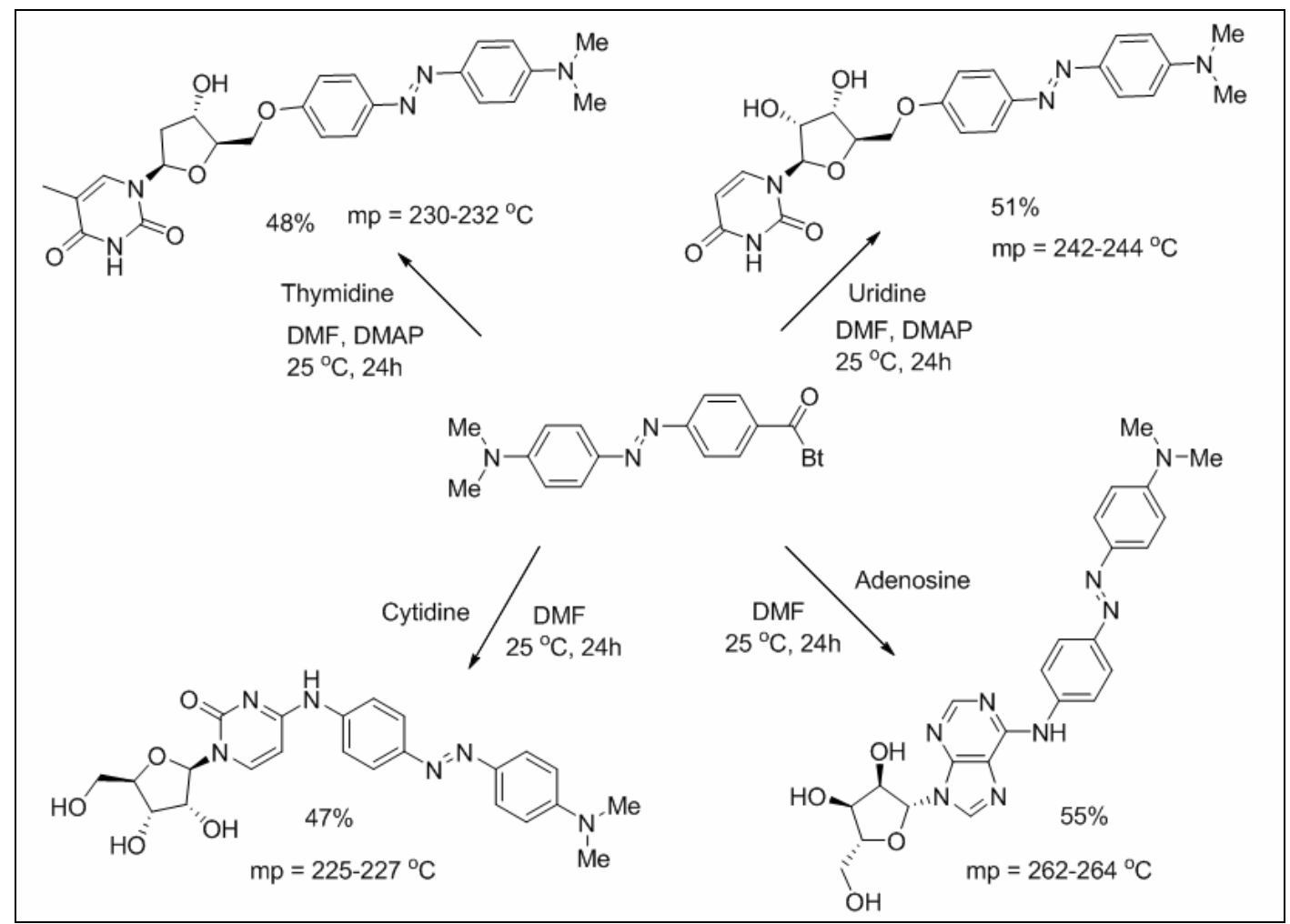

Figure 13. Preparation of dye- labeled nucleosides. ${ }^{11}$

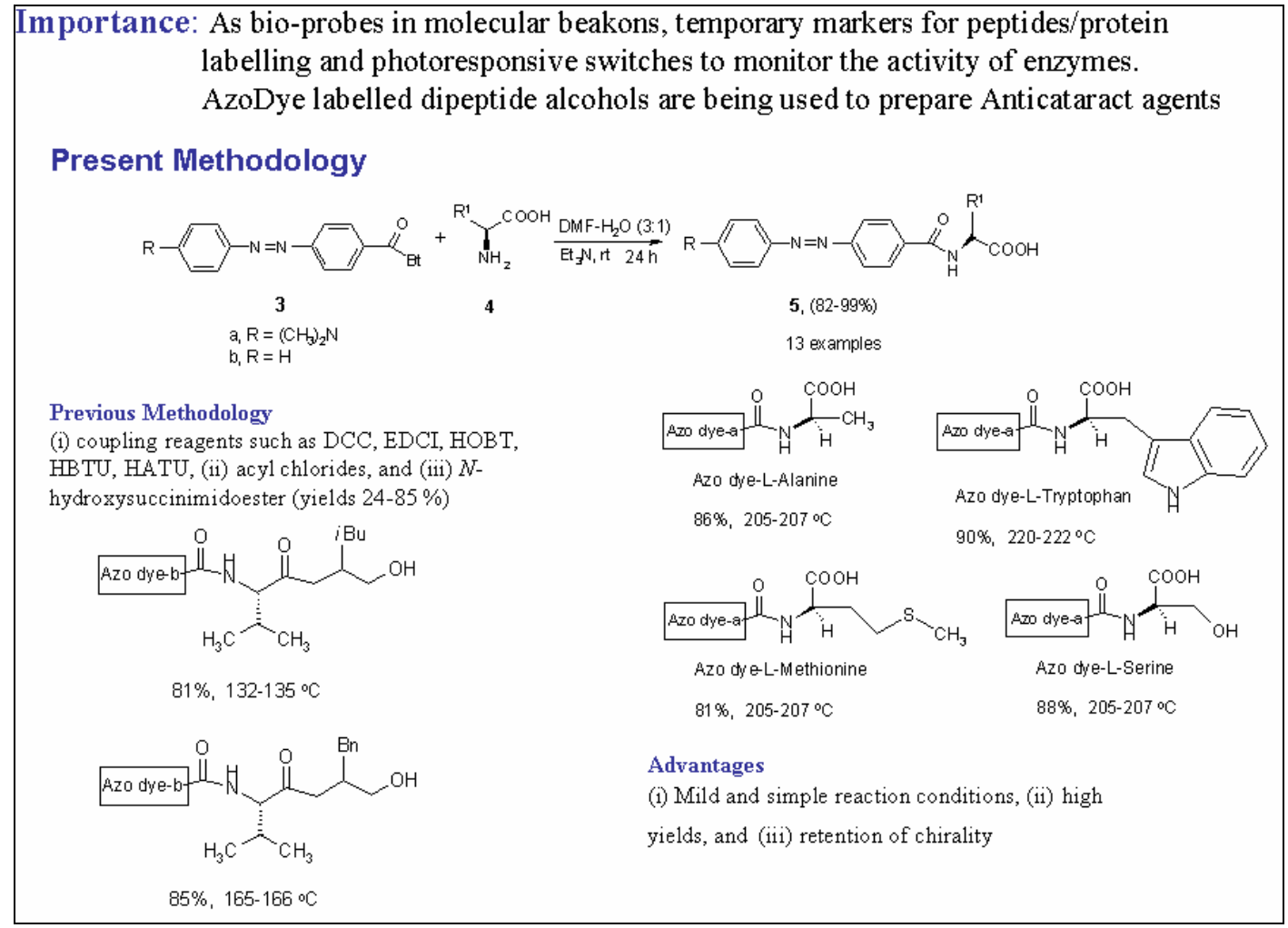

Figure 14. Synthesis of azo-dye- labeled amino acids and dipeptide alcohols. ${ }^{12}$ 


\section{Attempts to help Chemistry in Developing Countries by Innovations in the Publishing and Dissemination of Organic Chemistry Research}

The problems faced by libraries in meeting the high subscriptions required by commercial publishers are well known. The subscriptions set by learned societies for access to their publications are also high. This has given rise to the so-called "open access journals" where there is no charge to the reader, but page charges are levied on authors. In these circumstances it was decided eight years ago to launch a new journal with a very different philosophy: it would be free to authors, with no page charges or other fees, and also free to readers with no access or downloading charges. Thus Arkivoc was designed for universal on-demand distribution at no cost to authors or subscribers (see Figure 15).

\section{Subscription Journals}

(no charge to authors / Library pays)

European J. Org. Chem. $(\$ 4933)$

J. Org. Chem. (\$2500)

Tetrahedron $(\$ 16,756)$

Tetrahedron Letters $(\$ 12,204)$

Synthesis $(\$ 1900)$

Synlett $(\$ 1300)$
Open Access Journals

(no charge to reader; pages

charged to authors)

Bio. and Med. Chem.

Beilstein J. Org. Chem.

Molecules
Objectives for Arkivoc

Free to authors No page charges or other fees

Free to readers No access or downloading fees

Designed for universal on-demand distribution at no cost to authors or subscribers

1. On WMW electronically - free for all to access

2. Web edition formatted in pages to allow downloading and binding into hard copy - for free

3. Hard copy edition also available to send to deposit library and by subscription - for payment

4. Is kept in perpetuity on several servers worldwide

Figure 15. Publishing of chemistry in 2008.

Many of the standard publishing procedures are used in Arkivoc, as detailed in Figure 16, but a major difference is that the "Control Board" which runs Arkivoc is unpaid. The composition of the Control Board as of spring 2008 is shown in Figure 17. 
1. Instructions for authors including template available at wmw.arkat-usa.org

2. Authors contact Coordinating Editor by e-mail with MS title, authors, brief abstract

3. Coordinating Editor designates MS reference number, Scientific Editor, and referees

4. MS sent to Referees by e-mail

5. Referees send reports to Scientific Editor by e-mail

6. Scientific Editor makes decision as to accept the paper as it is, to ask author to amend manuscript, to seek additional Referee comments, or to reject paper

7. Author revises MS to satisfaction of Scientific Editor

8. Scientific Editor corresponds with authors until manuscript is accepted or rejected

9. Accepted manuscript sent to Publishing Editor, who arranges for technical editing and sending in for posting on the web

Figure 16. Submitting, refereeing and editing of manuscripts in ARKIVOC.

Referee Assigners: E. Anders (U. Jena, Germany), A. J. Boulton (also

Coordinating Ed, UEA, UK), W. Dolbier (U. Florida, USA),

B. Wakefield (U. Leeds, UK)

Scientific Editors: M. Begtrup (Roy. Sch. Pharmacy, Denmark),

G. Cirrincione (U. Palermo, Italy), M. A. Iglesias- Arteaga (Nat U Mexico),

H. Ila (Indian Inst Sci Kanpur), J. Joule (U. Manchester, UK),

A. Kotali (U. Thessaloniki, Greece), P. Krapcho (U. Vermont, USA),

B. Maes (U. Antwerp, Belgium), A. Marchand (Coral En, Inc.),

R. Muthyala (U. Minnesota, USA), C. Ramsden (Keele U., UK),

J. Schantl (U. Innsbruck, Austria), C. Stevens (Ghent U., Belgium),

A. Waring (U. Birmingham, UK), V. Zhdankin (U. Minnesota, USA)

Technical Editors: R. Murugan (Vertellus, Indianapolis, USA),

A. Sherman (Coll. Notre Dame, Maryland, USA)

Publishing Editor: E. Scriven (U. Florida, USA)

Web Auditor: A. J. Aanonson (Brunel U., UK)

Arkivoc, Flohet, Administrator: C.D. Hall (U. Florida, USA)

Steering Committee Chair: (A. R. Katritzky, U. Florida, USA)

Honorary Advisory Board: A. Bader, D. Curran, W. Doering, H. Kroto, J. Lehn, M. Makosza, V. Minkin. K. Nakanish. A. Padwa, B. Sharpless, T. Tidwell,L. Tietze

Figure 17. ARKIVOC organization: Control Board as of March 2008. 
We also have a very large Editorial Board of Referees. This has recently been extended significantly, and we now have close to 1,000 members. One difference from most editorial boards of referees is that we have about half our members from outside Western Europe, North America or Japan (see Figures 18 and 19) for representative lists.

During the eight years of existence, Arkivoc has progressed significantly in the number of manuscripts received and published. The number of visitors to its website has also increased dramatically; we now have about 100,000 visitors per month who make more than a million hits per month on the website.

\begin{tabular}{|c|c|c|}
\hline Austria: U. Brinker, J. Froehlich, P. & G.Doddi, G. Favaro, S. Florio, L. & Sandford, J. Shorter, K. Smith, E. \\
\hline Gaertner, N. Haider, C. O. Kappe, & Forlani, P. Fornasiero, F. Fringuelli, & Thomas, J. Walton \\
\hline M. D. Mihovilovic, T. Rosenau, M. & A. Gasco, G. La Manna, P. Linda, & United States: A.Fattah,R. \\
\hline irch, P. Stanetty & A. Maia, G. Musumarra, F. Naso, R. & Abramovitch, P. Angrish, D. Arya, R. \\
\hline Belgium: K. Abbaspour Tehrani, N. & Noto, M. Peruzzini, M. Pulici, G. & Asolkar, W. Bailey, A. Balaban, \\
\hline Kimpe, W. Dehaen, M. D'hooghe, R. & Scorrano, G. Sindona, D. Spinelli, L. & B.Banik, S. Berthel, N. Bharti, E. \\
\hline Dommisse, L.Ghosez, A. Krief, & Troisi, E. Valentin, P. Zanirato & Biehl,N. Bodor, D. Bonchev, S. \\
\hline I. Marko, C. Stevens, J. Vanden & Japan: M. Abe, K. Akiba, Y. & Branz, J. Brown, X. Bu, J. Byers, C. \\
\hline Eynde, G. Verniest & Asakawa, T. Haino, Y. Hayakawa,M. & Cantrell, T. Chandra, M. Charton, H. \\
\hline Canada: E. Buncel, K. Darvesh, T. & Hayashi, N. Nishiwaki, K. Orito,Y. & Chen, G. Cherukupalli, S. \\
\hline Fyles, P. Georghiou, J. Kresge, T. & Takeuchi, M. Tanaka, J. Tatsugi, & Chittaboina, M. Chorghade, D. \\
\hline H. Muchall, T. Ollevier, & T.Toru, Y. Yamamoto, T. Yokomatsu & Comins, D. Dalton, S. De, R. \\
\hline Tidwell & ands: L. Jenneskens, R. & Dembinski, S. Deng, G. Dong, A. \\
\hline Denmark: J. Becher, M. Begtrup, P. & Kellogg & Dutta, F. Ebetino, L. Echegoyen, E. \\
\hline Hansen & Norway: J. Bakk & Enholm, A. Franz, A. Fry, R. Glass, \\
\hline Finland: K. Klika, M. Oivanen, K. & Rise, K. Undheim & D. Glueck, M. Harmata, T. Harris, L. \\
\hline E. Sievänen & Portugal: P. Almeida, A. Lobo,C. & Hawkins, N. Hebert, R. Hinkle, C. \\
\hline France: C. Amatore, G. Balme, G. & a, A. Oliveira-Campos,A. & Hulme, M. Ilies, S. Janaswamy, G. \\
\hline Bashiardes, J. Bazureau, T. Besson, & Silva & Jones, S. Jonnalagadda, F. Kang, A. \\
\hline P. Bonnet, P. Dauban, J. Fehrentz, J. & M. Alvarez, J. & Katritzky, D. Ketcha, J. Kiely, R. \\
\hline Finet, C. Gerardin, G. Kirsch, & Alvarez-Builla, M. Amat, J. & Kinnel, P. Kiprof, K. Kirichenko, H. \\
\hline A. Lattes, C. Laurence, C. Le Roux, & znar, J. & P. Krapcho, S. Kumar, I. \\
\hline J. Majoral, M. Malacria, J. Mattalia, & lández Bolaños, J. & Lalezari, H. Lang, V. Lobanov, A. \\
\hline edebielle, G. Queguiner, & C. Cativiela, R. & Marchand, A. Martin, T. Masquelin, \\
\hline sel, D. Sinou, F. Terrier, & Claramunt, D. Diez, E. Díez-Barra, J. & N. Meanwell, R. Millar, G. \\
\hline G. Vo-Thanh & B. Fontaniella, V. Gotor, C. & Mittapalli, P. Mohapatra, R. \\
\hline Germany: E. Anders, M. & Cortes, J. & in, R. Muthyala, V. Nair, K. \\
\hline Balaban, R. Beckert, P. Czerney, U. & Menendez, P. Merino, P.Molina, M. & Nakanishi, T. Nalli, G. Negrete, G. \\
\hline Dietrich, D. Edelmann, W.Huebsch, & F. Palacios, C. Palomo, M. & Newkome, E. Olson, D. Ostercamp, \\
\hline H. Ihmels, K. Jug, & Plumet, E. Roman, R. Suau, & P. Otten, A. PadwaD. Palmer, K. \\
\hline hn, T. Kurz, H. Martin, P. & ga, T. Torroba, M. Yus & Pankiewicz, C. Parkanyi, A. Pathak, \\
\hline Montforts, $\mathrm{S}$. & n, S. Grivas, T. & E. Pelkey, D. Pleynet, G. Prakash, M. \\
\hline Nerdinger, P. Rademacher, N. Risch, & J. Stawinski & Quirke, T. Ramachandar, M. Reddy, \\
\hline H. Wamhoff, E. & leimgartner, $\mathrm{C}$. & C. Reddy, M.Mohan Reddy, J. \\
\hline Wue & Jefford & Richard, N. Richards, S. Roy, S. Roy, \\
\hline Ireland: R. Butler & Afarinkia, A. & J. Russel, S. Sabesan, V. Samano, M. \\
\hline y, A. Maguire, R. & Allen & M. Saulnier, E. \\
\hline 11, H. Moynihan & , S. Bew, R. Chambers, R. & Scriven, Y. Sham, I.Shcherbakova, T. \\
\hline Italy: A. Almerico, A. Andreani, L & Coombes, M. Cronin, A. de Silva,I. & Singh, H. Sintim, M. Siskin, K. \\
\hline Angiolini, O. Attanasi, M. Aversa, & Eggleston, C. Frost, L. Harwood, H. & Smith, X. Song, P. Srirama Sarma, C. \\
\hline U. Azzena, E. Baciocchi, R. Ballini, & W. Horspool,H. Hudson,K. & Stephens, L. Strekowski, B. Terem, \\
\hline M. Catellani, L. Ceraulo, F. Cerı & Jones, R. Jones, J. Joule, N. Karodia, & K. Turnbull, A.Vakulenko, C. \\
\hline & D.Kelly, W. Kerr, P. Knowles, B. & Verbicky, R. Walczak, M. Walker, A. \\
\hline Chimichi, G. Cirrincione, M. Costi, & Linclau, S. Marsden, H. Maskill,T. & Wilcox, S. Wiskur, D. Wright, M. \\
\hline G. Daidone, R. Dalpozzo, M. & ey, C. Moody, P. Murphy, & Wright, K. Wu, T. Wu, J. Yevich, Y. \\
\hline aria, A. & G. Pattenden, M. Plate, C. & Yuan, Y. Zhang, Y. Zhang,V. \\
\hline Degli'Innocenti, G. Desimoni, & Ramsden, D. Rees, C. Reese, G. & Zhdankin, C. Zhou, P. Zuman \\
\hline
\end{tabular}

Figure 18. ARKIVOC Editorial Board of Referees: members from W. Europe, N. America, Japan. 


\begin{tabular}{|c|c|}
\hline Argentina: Alicia Baldessari, Maria T. Baumgartner, & Valentina K. Yu \\
\hline Graciela Yolanda Buldain, Rita Hoyos de Rossi, Teodoro & Korea: SouthHyun-Joon Ha, Yogesh R. Jorapur, Byeang \\
\hline S. Kaufman, Graciela Y. Moltrasio, Norma Sbarbati & Hyean Kim, Jae Nyoung Kim, Seokjoon Lee \\
\hline Nudelman, Alicia Penenory, Adriana B. Pierini, Julio C. & Kuwait: Nouria Al-Awadi \\
\hline Podesta, Javier Ramirez, Roberto A. Rossi, Juana J. & Latvia: Pavel Arsenyan, Gunars Duburs, Edmunds \\
\hline Silber, Patricia Vazquez & Lukevics \\
\hline Australia: Roger Bishop, David Black, Robert T. C. & Lebanon: M. Haddadin \\
\hline Brownlee, Darren Cundy, Chris J. Easton, Robin G. F. & Libya: George Y. Sarkis \\
\hline Giles, Stephen Glover, Andrew Hughes, Bill Kitching, & Malaysia: Zuriati Zakaria \\
\hline Patrick Perlmutter, Jack Ryan, Paul Savage, Jamie & Mexico: Armando Ariza-Castolo, Carlos M. Cerda, \\
\hline Simpson, Bela Ternai, Curt Wentrup, Jonathan M. White & Gabriel Cuevas, Francisco Delgado, Guillermo Delgado, \\
\hline Bangladesh: M. Giasuddin Ahmed & Norberto Farfan, Felipe J. González, Barbara Gordillo, \\
\hline Belarus: Alexander V. Baranovsky & Eusebio Juaristi, Roberto Martinez, Rachel Mata, René \\
\hline Brazil: Wilhelm Josef Baader, Ivan P. de A. Campos, & Miranda, \\
\hline Paulo Cesar de Jesus, Luiz Carlos Dias, Ronaldo Pilli, & Mario Ordóñez, Angeles Paz-Sandoval, Eduardo Peña- \\
\hline Jose Augusto Rosario Rodrigues, Marcus M. Sa, Dulce & Cabrera, Rosa Santillan, Joaquin Tamariz \\
\hline Helena Siqueira Silva, Marcos Souza, Blanka Wladislaw & Moldova: Fliur Macaev \\
\hline Bulgaria: Ivan G. Binev, Vladimir Dimitrov, Ivan G. & New Zealand: Jim Coxon, Brian Halton, Gordon \\
\hline Pojarlieff & Rewcastle, Peter J. Steel \\
\hline Chile: Julio Belmar Mellado, Bruce Cassels, Marcos & Poland: Ryszard Bodalski, Dariusz Bogdal, Jacek \\
\hline Caroli Rezende & Brzezinski, Marek Chmielewski, Zofia Dega-Szafran, \\
\hline China: Shujiang Tu, Mei-Xiang Wang, Z. F. Xi, Deqing & Tomasz Janecki, Janusz Jurczak, Andrzej Kapturkiewicz, \\
\hline Zhang, Yongmin Zhang, Zhan-Hui Zhang, Guisen Zhao, & T. Marek Krygowski, Jaroslaw Lewkowski, Barbara \\
\hline Jian-Ping Zou & Malawska, Roman Mazurkiewicz, Jan Michalski, Jacek \\
\hline Croatia: Mirjana Eckert-Maksic, Bono Lucic, Kata & W. Morzycki, Wieslaw Oleszek, Jerzy Suwinski, \\
\hline Mlinaric-Majerski, Marin Roje, Nenad TrinajsticHrvoj & Miroslaw Szafran, Piotr Tomasik \\
\hline Vancik & Puerto Rico: John A. Soderquist \\
\hline Cuba: Daniel Garcia-Rivera, Carlos Perez, Margarita & Romania: Vasile N. Bercean, Florea Dumitrascu, Petru \\
\hline Suarez Navarro & Filip, Florentina Georgescu, Ionel I. Mangalagiu, Vasile I. \\
\hline Cyprus: Panayiotis A. Koutentis & Parvulescu, Alexandru C. Razu,s \\
\hline Czech Republic: Stanislav Radl & Russia: Vadim Annenkov, Eugene Babaev, Shainyan \\
\hline Egypt: Ashraf A. Aly, El Sayed H. El Ashry, Ayman El- & Bagrat, Vasiliy Bakulev, Leonid Belen'kii, Irina \\
\hline Faham, A. S. Hamad Elgazwy, Mohamed Helmy Elnagdi, & Beletskaya, Konstantin Bryliakov, Andrei Ershov, Nina \\
\hline A. Heshmat Moustafa, & Gusarova, Nadezhda Itsikson, Andrey Ivanov, Rem \\
\hline Estonia: Mati Karelson, Uno Mäeorg, Uko Maran & Kostyanovsky, Mikhail Kuznetsov, Alevtina Medvedeva, \\
\hline Greece: John K. Gallos, Michael Orfanopoulos, & Nina Nedolya, Vladimir Ostrovskii, Anatolii Pomogailo, \\
\hline Anastasios Varvoglis, GeorgeVarvounis & Alexander Pozharskii, Valery Traven, Alexey Trofimov, \\
\hline Hong Kong: Wei-Min Dai & Sergei Vasilevsky, Natalia Vlasova, Mikhail Voronkov, \\
\hline Hungary: Ferenc Fülöp, Gyorgy Hajos, Kalman Hideg, & Nikolai Zefirov \\
\hline Albert Lévai, Peter Molnar, József Nyitrai & Saudi Arabia: Ashraf Ghanem \\
\hline India: Rajkumar Bansal, Deevi Basavaiah, Chinnappan & Serbia: Ivan Juranic, Rade Markovic \\
\hline Baskar, D. Subhas Bose, Ramesh Chandra, S. & Slovakia: Lubor Fišera, Alzbeta Krutosikova, Viktor \\
\hline Chandrasekhar, Biswanath Das, Asish De, Rina Ghosh, & Milata, Ladislav Petrus \\
\hline Subrata Ghosh, Hiriyakkanavar Ila, Javed Iqbal, Sanjay & Slovenia: Jernej Iskra, Danijel Kikelj, Slovenko Polanc, \\
\hline Jain, N. N. Joshi, H. Junjappa, Srinivas Kantevari, & Branko Stanovnik, Jurij Svete \\
\hline Sambasivarao R. Kotha, Devinder Kumar, G. & South Africa: Jaco Breytenbach, Ivan Green, Roger \\
\hline Kumaraswamy, Alka Mital, D. K. Mohapatra, Satbir Mor, & Hunter, Perry T. Kaye, Joseph P. Michael \\
\hline Ganesh Pandey, Virinder S. Parmar, Mariappan & Taiwan: Long-Yong Chiang, Reuben Jih-Ru Hwu, Tien- \\
\hline Periasamy, S. Perumal, Om Prakash, Thingalur K. Raja, & Yau Luh, Chin-Kang Sha \\
\hline A. V. Rama Rao, B. C. Ranu, Diwan S. Rawat, Anil & Trinidad and Tobago: Gurdial Singh \\
\hline Kumar Saxena, G. V. M. Sharma, M. S. Shashidhar, & Turkey: Esin Aki-Sener, K. Husnu Can Baser, Sevim \\
\hline Vishwakarma Singh, Neelima Sinha, A. Srikrishna, G. S. & Bilgic, Nihat Celebi, Necdet Coskun, Mustafa Güllü, \\
\hline R. Subba Rao, G. Sundararajan, Yashwant D. Vankar, & Cemil Ibis, Cemil Ogretir, Ismail Ozdemir, Turan Ozturk, \\
\hline Shirodkar Prabhakar Yeshawant, IranMohammad Reza & Bilge Sener, Süleyman Servi, Birsen Tozkoparan, Lemi \\
\hline Islami, Kazem Saidi, Hassan Sheibani, Issa Yavari, & Turker \\
\hline Mohammad Ali Zolfigol & Ukraine: Dmitriy Volochnyuk \\
\hline Israel: Eli Breuer, Alfred Hassner, Shmaryahu Hoz & Uruguay: Hugo Cerecetto, Horacio Heinzen \\
\hline Jamaica: Yvette Jackson & Uzbekistan: Andrey A. Toropov \\
\hline Kazakhstan: Svetlana Achmetshakirovna Vizer, & Venezuela: Franklin Vargas \\
\hline
\end{tabular}

Figure 19. ARKIVOC Editorial Board of Referees: members from outside W. Europe, N. America, Japan. 
An important part of the philosophy of ARKIVOC is to honor chemists from around the world. Distinguished scientists, including chemists, have long been honored in their own countries and a small number, mainly from a few Western developed countries, are honored internationally. Arkivoc has chosen to recognize chemists from around the world and, so far we have produced 85 commemorative issues (Figure 20).

\begin{tabular}{|c|c|c|}
\hline Country & Year & Chemist \\
\hline \multirow[t]{3}{*}{ Argentina } & 2003 & Rossi \\
\hline & 2003 & Ruveda \\
\hline & 2005 & Ledekremer \\
\hline Austria & 2001 & Sauter \\
\hline \multirow[t]{2}{*}{ Australia } & 2001 & Cameron \\
\hline & 2004 & Rickards \\
\hline \multirow[t]{2}{*}{ Belgium } & 2003 & Hoornaert \\
\hline & 2007 & Krief \\
\hline Belarus & 2008 & Kulinkovich \\
\hline Bulgaria & 2009 & Conference \\
\hline Botswana & 2007 & Abegaz \\
\hline Brazil & 2004 & Gottlieb \\
\hline \multirow[t]{3}{*}{ Canada } & 2001 & Tee \\
\hline & 2002 & Muchowski \\
\hline & 2009 & Sorensen \\
\hline \multirow[t]{2}{*}{ China } & 2003 & Huang \\
\hline & 2004 & Yuan \\
\hline Croatia & 2002 & Sunko \\
\hline \multirow[t]{2}{*}{ Finland } & 2001 & Pihlaja \\
\hline & 2009 & Lonnberg \\
\hline \multirow[t]{3}{*}{ France } & 2006 & Lattes \\
\hline & 2008 & Queguiner \\
\hline & 2008 & Solladie- Cavalle \\
\hline \multirow[t]{4}{*}{ Germany } & 2004 & Krohn \\
\hline & 2007 & Adam \\
\hline & 2007 & Anders \\
\hline & 2007 & Tietze \\
\hline Greece & 2003 & $\mathrm{~V}$ arvoglis \\
\hline
\end{tabular}

\begin{tabular}{|c|c|c|}
\hline Country & Year & Chemist \\
\hline Holland & 2004 & Zwanenburg \\
\hline \multirow{3}{*}{ Hungary } & 2003 & Bernath \\
\hline & 2004 & Antus \\
\hline & 2008 & Szantay \\
\hline \multirow[t]{8}{*}{ India } & 2001 & Govindachari \\
\hline & 2002 & Kessar \\
\hline & 2003 & Chatterje \\
\hline & 2004 & Sukh Dev \\
\hline & 2005 & Narismhan \\
\hline & 2005 & Anand \\
\hline & 2005 & Rao \\
\hline & 2005 & Swaminathan \\
\hline Israel & 2001 & Hassner \\
\hline \multirow[t]{6}{*}{ Italy } & 2002 & Spinelli \\
\hline & 2004 & Tortorella \\
\hline & 2006 & Bartoli \\
\hline & 2006 & ICHC Conf. \\
\hline & 2006 & Med. Chem. Conf. \\
\hline & 2009 & Vivona \\
\hline \multirow[t]{2}{*}{ Japan } & 2003 & Fukumoto \\
\hline & 2009 & Tomoya \\
\hline Kuwait & 2008 & Al- Awadi \\
\hline Latvia & 2006 & Lukevics \\
\hline \multirow[t]{3}{*}{ Mexico } & 2003 & Regional Issue \\
\hline & 2005 & Juaristi \\
\hline & 2008 & Contreras \\
\hline $\mathrm{NZ}$ & 2006 & Coxon \\
\hline Norway & 2001 & Undheim \\
\hline
\end{tabular}

\begin{tabular}{|c|c|c|}
\hline Country & Year & Chemist \\
\hline Pakistan & 2007 & Rahman \\
\hline \multirow[t]{2}{*}{ Poland } & 2004 & Makosza \\
\hline & 2007 & Epstajn \\
\hline \multirow[t]{2}{*}{ Romania } & 2002 & Nenitzescu \\
\hline & 2005 & Balaban \\
\hline \multirow[t]{8}{*}{ Russia } & 2001 & Voronkov \\
\hline & 2003 & Trofimov \\
\hline & 2004 & Chupakhin \\
\hline & 2004 & Konovalov \\
\hline & 2005 & Minkin \\
\hline & 2005 & Zefirov \\
\hline & 2008 & Beletskaya \\
\hline & 2009 & Pozharskii \\
\hline Slovakia & 2005 & Fisera \\
\hline \multirow[t]{2}{*}{ Slovenia } & 2001 & Tisler \\
\hline & 2003 & Stanovnik \\
\hline S. Africa & 2002 & Bull \\
\hline Sweden & 2008 & Norin \\
\hline Ukraine & 2005 & Regional Issue \\
\hline \multirow[t]{4}{*}{ UK } & 2000 & Jones \\
\hline & 2000 & Meth-Cohn \\
\hline & 2002 & Lloyd \\
\hline & 2002 & Rees \\
\hline \multirow[t]{6}{*}{ USA } & 2001 & Abramovitch \\
\hline & 2001 & Thyagaragan \\
\hline & 2002 & Karabatsos \\
\hline & 2002 & Padwa \\
\hline & 2003 & Shine \\
\hline & 2007 & Joulle \\
\hline
\end{tabular}

Figure 20. 2000- 2009: 85 Chemists honored from 33 countries.

Our impact factor has risen steadily and has now overtaken that of several other journals (Figure 21); while it is still well below that of the best journals in organic chemistry, we hope that the increase in our impact factor will continue.

We have also tried to improve contacts between chemists worldwide by running an annual heterocyclic and synthetic conference at the University of Florida. At this conference we offer a dozen plenary lectures from some of the world's most distinguished chemists (Figure 22) together with short courses on various aspects of organic chemistry, 20-30 invited lectures, some 60 posters, and a full social program. Figure 23 shows the program for the 2008 conference. 


\begin{tabular}{|l|l|l|l|l|l|l|l|}
\hline Year & Arkivoc & Molecules & JHetC & Heterocycles & $\begin{array}{l}\text { Synthetic } \\
\text { Comm. }\end{array}$ & Synthesis & JOC \\
\hline 2000 & - & 0.182 & 0.781 & 1.015 & 0.828 & 2.193 & 3.689 \\
\hline 2001 & - & 0.223 & 0.746 & 0.970 & 0.912 & 1.985 & 3.280 \\
\hline 2002 & - & 0.408 & 0.701 & 1.045 & 0.802 & 2.201 & 3.217 \\
\hline 2003 & 0.392 & 0.911 & 0.711 & 1.082 & 0.853 & 2.074 & 3.297 \\
\hline 2004 & 0.418 & 0.676 & 0.814 & 1.064 & 0.965 & 2.203 & 3.462 \\
\hline 2005 & 0.694 & 1.113 & 0.735 & 1.070 & 0.860 & 2.401 & 3.675 \\
\hline 2006 & 0.800 & 0.841 & 0.776 & 1.077 & 1.001 & 2.333 & 3.790 \\
\hline 2007 & 1.253 & 0.940 & 0.813 & 1.066 & 0.977 & 2.257 & 3.959 \\
\hline
\end{tabular}

Figure 21. ARKIVOC Impact Factor.

\begin{tabular}{|c|c|c|c|c|c|c|c|c|c|c|c|}
\hline Name & Year & Country & Name & Year & Country & Name & Year & County & Name & Year & Country \\
\hline E. Anders & 2002 & Germany & $\vee$. Farina & 2008 & Belgium & G. Mehta & 2007 & India & J. Schwarz & 2006 & USA \\
\hline J.A.rmstrong & 2004 & USA & J. Froehlich & 2000 & Austria & N. Meanwell & 2007 & USA & E. Scriven & 2000 & USA \\
\hline J. Eackval & 2008 & Sweden & G. Fu & 2006 & USA & B.Maryanott & 2006 & USA & J. Sisko & 2002 & USA \\
\hline J. Bakke & 2003 & Nowway & A.Furstner & $2005 / 7$ & Germany & G. Mehta & 2006 & India & B.Snider & 2007 & USA \\
\hline J.Barluenga & 2002 & Spain & B.Ganem & 2006 & USA & A. Meijere & 2008 & Germany & V.Snieckus & 2000 & Canada \\
\hline M. Begtrup & 2005 & Denmark & G.Gribble & 2003 & USA & O.Meth-Cohn & 2000 & UK & B. Stanovnik & 2001 & Slovenia \\
\hline J.Bergman & 2007 & Sweden & R. Grigg & 2002 & UK & V. Minkin & 2001 & Russia & G.S.R. Rao & 2003 & India \\
\hline I.Beletskaya & 2002 & Russia & R.Grubbs & 2003 & USA & M. Mitchell & 2001 & USA & R. Taylor & 2006 & UK \\
\hline S. Benner & 2001 & USA & K. Hafner & 2000 & Germany & G. Molander & 2001 & USA & T. Tidwell & 2004 & Canada \\
\hline S.Blechert & 2003 & Germany & S.Hecht & 2003 & USA & C.J. Moody & 2007 & UK & L. Tietze & 2004 & Germany \\
\hline N. Bodor & 2002 & USA & P.Hodgson & 2005 & UK & G.Molander & 2005 & USA & B. Trotimov & 2000 & Russia \\
\hline D. Boger & 2005 & UK & P. Jacobi & 2008 & USA & T.Mukaiyaa & 2000 & Japan & B. Trost & 2006 & USA \\
\hline M.Erimble & 2005 & $N Z$ & G. Johnson & 2002 & USA & G.Newkome & 2001 & USA & J. Vollharct & 2007 & USA \\
\hline J. Bristol & 2007 & USA & J. Joule & 2005 & UK & P. Ornstein & 2004 & USA & S. Volante & 2006 & USA \\
\hline M. Butters & 2003 & UK & C. Kappe & 2008 & Austria & A. Pachwa & 2004 & USA & S. von Unge & 2003 & Sweden \\
\hline D. Comins & 2000 & USA & J. Kiely & 2000 & USA & G.Pattenden & 2008 & UK & J. Stoddart & 2007 & USA \\
\hline P.Canfalone & 2001 & USA & S. King & 2008 & USA & W. Pearson & 2002 & USA & A. Whittle & 2007 & UK \\
\hline D. Curran & 2002 & USA & P. Knochel & 2007 & Germany & N.Petasis & 2002 & USA & S. Weinrab & 2008 & USA \\
\hline A. Czarnik & 2004 & USA & S.Kobayash & 2003 & Japan & G.Queguine & 2004 & France & P. Mipt & 2008 & USA \\
\hline N. Kimpe & 2003 & Belgium & H. Kroto & 2008 & USA & A.V. Rao & 2005 & India & P. Wuts & 2002 & USA \\
\hline M. deLong & 2005 & USA & P. Lam & 2008 & USA & C. Ramsden & 2001 & UK & Y.Yamamoto & 2001 & Japan \\
\hline S.Denmark & 2005 & USA & R. Larson & 2007 & USA & C. Rees & 2004 & UK & H. Yamamoto & 2006 & USA \\
\hline W. Dolbier & 2006 & USA & R. Larock & 2005 & USA & H. Reissig & 2007 & Germany & M. Yus & 2003 & Spain \\
\hline S. Dondoni & 2000 & Italy & J. Macor & 2004 & USA & M. Reetz & 2006 & Germany & T. Zhang & 2008 & USA \\
\hline P. Dunn & 2001 & UK & M. Makosza & 2001 & Polan & J. Sanders & 2004 & UK & & & \\
\hline J.Ellman & 2004 & USA & M.Martinelli & 2000 & USA & J.Schantl & 2002 & Austria & & & \\
\hline
\end{tabular}

Figure 22. Plenary lectures at Flohet, 2000-2008. 


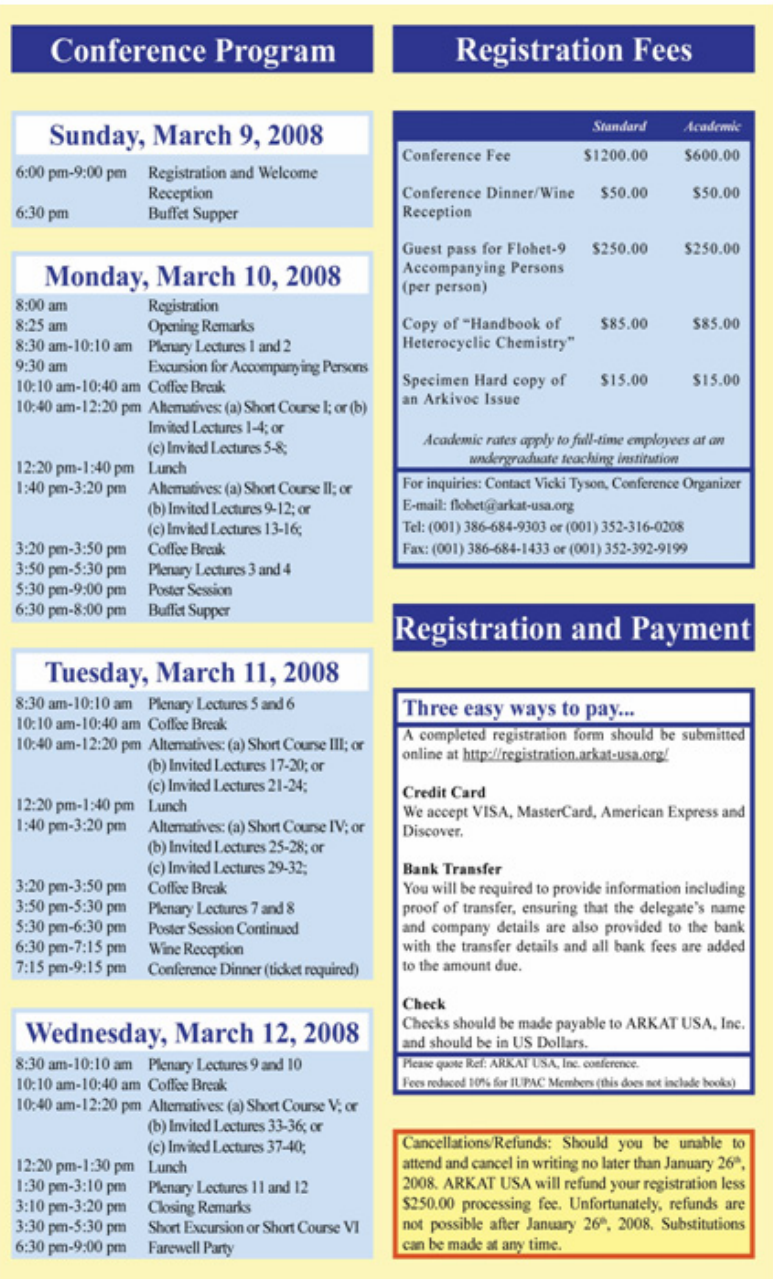

\begin{tabular}{|c|}
\hline Introduction to FloHet - 9 \\
\hline $\begin{array}{l}\text { Eight previous Florida Conferences held each March for the years } 2000 \text { through } \\
2007 \text { inclusive, brought together the academic and industrial communities with } \\
\text { an abundance of heterocyclic and synthetic chemistry reflecting the current } \\
\text { interest in the subject. The program holds particular interest for the industrial } \\
\text { chemical community where pharmaceuticals, agrochemicals and colorants } \\
\text { usually contain at least one heterocyclic ring. }\end{array}$ \\
\hline $\begin{array}{l}\text { This, the Ninth Florida Heterocyclic and Synthetic Conference, continues in the } \\
\text { tradition of its highly successful predecessors. Registration will start on } \\
\text { Sunday, March } 9^{\text {th }} \text { with a Welcome Reception. On Monday the } 10^{\text {th through }} \\
\text { Wednesday the } 12^{\text {th }} \text {, the Conference will feature twelve plenary lectures given } \\
\text { by academic and industrial experts from around the world together with invited } \\
\text { lectures and short courses on heterocyclic topics. A poster session combined } \\
\text { with a buffet supper will be held on the evening of Monday, March } 10^{\text {th }} \text {. A wine } \\
\text { reception and conference banquet are scheduled for the evening of Tuesday, } \\
\text { March } 11^{\text {th }} \text {. The conference closes with a farewell party on the evening of } \\
\text { Wednesday, March } 12^{\text {th. }}\end{array}$ \\
\hline Plenary Speakers \\
\hline 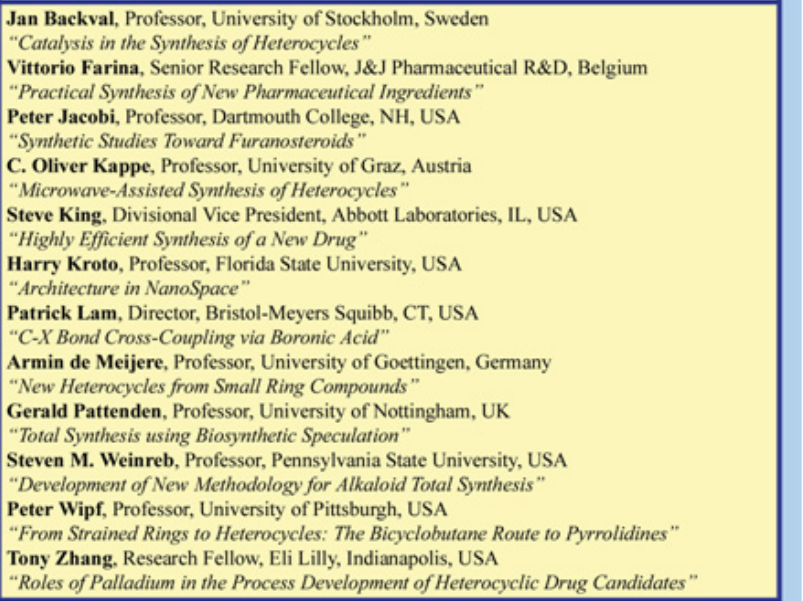 \\
\hline
\end{tabular}

Figure 23. Conference Program at Flohet in 2008.

We hope that all chemists will help our efforts to extend the hand of friendship to organic chemists all around the world. We now have a rather high rejection rate for Arkivoc, but if you submit a manuscript we will try to provide you with constructive criticism that may be helpful even if it is rejected. We hope that you will access ARKIVOC and, when relevant, cite ARKIVOC; the subject index will help you find suitable papers.

We also hope that you will consider coming to the Flohet conference; it gives excellent value and all profits go to support ARKIVOC. We only regret that we cannot reduce fees or give any awards because the whole operation of ARKIVOC and Flohet occurs without major support and is only made possible by the unstinting efforts of a large number of community-minded chemists. 


\section{References}

1. Suryanarayana, M. V. S.; Pandey, K. S.; Prakash, S.; Raghuveeran, C. D.; Dangi, R. S.; Swamy, R. V., Rao; K. M. J. Pharm. Sci. 1991, 80, 1055.

2. Gupta R. K.; Bhattacharjee A. K. in Insect Repellents: Principles, Methods and Uses, Debboun, M.; Frances, S.P.; Strickman, D., CRC Press: Taylor\& Francis Group, Boca Raton, London, New York, 2007, pp. 195-229.

3. (a) Katritzky, A. R., Suzuki; K., Wang Z. Synlett 2005, 11, 1656. (b) Katritzky, A. R.; Zhang, Y.; Singh, S. K. Synthesis 2003, 2795.

4. Haase, D.; Johnson, J.; and Chung, A., unpublished work.

5. Katritzky, A. R.; El-Gendy, B. E.-D. M.; Todadze; Abdel-Fattah A. A. A. J. Org. Chem. 2008, 73, 5442.

6. Katritzky, A. R.; Angrish, P. Synthesis 2006, 4135.

7. Katritzky, A. R.; Angrish, P. Steroids 2006, 71, 660.

8. Tala S.R; Nader, A. D., unpublished work.

9. Katritzky, A. R.; Narindoshvili T.; Angrish, P. Synthesis 2008, 13, 2013.

10. Katritzky, A. R.; Cusido, J.; Narindoshvili T. Bioconjugate Chem. 2008, 19, 1471.

11. Khelashvili, L.; Kovacs, J., unpublished work.

12. Katritzky, A. R.; Chen Q.-Y.; Tala, S. R. Org. Biomol. Chem. 2008, 2400. 